\author{
Marcin ADA MCZYK
}

University of Wrocław, Faculty of Social Science, Poland

Patrycja RUTKOWSKA (D)

Nicolaus Copernicus University, Faculty of Political Science and Security Studies, Toruń, Poland

\title{
Analysis of the Foreign Policy of the Country through its Determinants, Structure and Instruments: Potential Research Scenarios
}

\author{
Analiza polityki zagranicznej państwa \\ przez pryzmat jej uwarunkowań, struktury oraz instrumentów - \\ potencjalne scenariusze badawcze
}

\section{- Abstrakt •}

Celem wiodącym niniejszej pracy jest przybliżenie możliwości badawczych, jakie daje analiza uwarunkowań, struktury oraz instrumentów polityki zagranicznej państwa. Wtórnym celem jest zaś prezentacja kilku potencjalnie interesujących scenariuszy badawczych z wykorzystaniem przedstawionego ujęcia. Na potrzeby niniejszych rozważań przytoczono wybrane definicje polityki zagranicznej funkcjonujące w głównym nurcie polskiej nauki (autorstwa czołowych badaczy stosunków międzynarodowych) oraz zawarte $\mathrm{w}$ anglojęzycznych publikacjach renomowanych wydawnictw zagranicznych. Następnie na ich podstawie zaproponowano autorską definicję polityki zagranicznej. W kolejnych podrozdziałach zawarto prezentację wybranych elementów analizy polityki zagranicznej w postaci jej uwarunkowań, struktury oraz instrumentów. W swoich badaniach autorzy wykorzystali wtórny mate-

\section{- Abstract •}

The main objective of this article is to present potential research opportunities offered by the analysis of conditions, structure and instruments of the foreign policy of the country. The secondary objective is to present several potentially interesting research scenarios using the presented approach. For the purpose of these analyses, selected definitions of foreign policy functioning in the mainstream of Polish science (by leading researchers of international relations) and included in English-language publications of renowned foreign publishers will be presented. Then, the authors' definition of foreign policy will be proposed based on these publications. In the following subsections there will be a presentation of selected elements of foreign policy analysis in the form of its determinants, structure and instruments. In their research, the authors used secondary research material in the form of scientific articles in Pol- 
riał badawczy w postaci opracowań naukowych w języku polskim i angielskim. W badaniach zastosowano metodę analizy treści.

Słowa kluczowe: analiza polityki zagranicznej; badanie polityki zagranicznej; uwarunkowania polityki zagranicznej; instrumenty polityki zagranicznej; struktura polityki zagranicznej ish and English. The method used in the research is the method of content analysis.

Keywords: foreign policy analysis; foreign policy research; foreign policy determinants; foreign policy instruments; foreign policy structure

Researcher of international relations nowadays possesses a wide range of research methods and techniques, not only from the catalogue of political sciences, but also from a number of other disciplines (even distant ones). This weatlh can sometimes confuse and hinder the choice of the potentially best approach to carrying out the intended research process. In order to at least partially reduce the scale of these inconveniences, we have decided to prepare an article aimed at presenting potential research opportunities offered by the analysis of the determinants, structure and instruments of the country's foreign policy. At the same time, we have decided to enrich our purely theoretical reflections with presentations of several probably attractive research scenarios in which the use of our approach may bring intriguing results.

At the beginning of our deliberations, however, it is worth noting that foreign policy is one of those concepts in political science which on the one hand is undoubtedly intuitively understandable, even for a layman (Neack, 2019, p. 7), and on the other hand, it has countless definitions - if only because its understanding is constantly evolving (Jaworski, 2010, pp. 141-144). For the purpose of these analyses, selected definitions of foreign policy functioning in the mainstream of Polish science (by leading researchers of international relations) and included in English-language publications of renowned foreign publishing houses will be quoted. Then our own definition will be proposed based on them. In the following subsections, we will present selected elements of foreign policy analysis in the form of its determinants, structure and instruments. The summary, however, will be a place where we will propose potentially promising research scenarios.

In our research we used secondary research material in the form of scientific papers in Polish and English. We have developed this material using a content analysis method. Interesting threads which lacked space for development will be signalled by appropriate links in the text. 


\section{Conceptualisation of Foreign Policy}

Roman Kuźniar perceives foreign policy as “(...) an organized and externally directed effort of the state, subordinated to the achievement of its vital interests, which is expressed in the shaping of its external environment (creating and promoting relations and favourable situations, preventing and eliminating unfavourable situations)" (Kuźniar, 2006, p. 122; Adamczyk \& Baraniuk, 2017, p. 43). According to Julian Sutor, it is: "the sovereign forming by competent state authorities of strategic national (state) goals (interests) on the international arena, in the short and long term, and a set of actions undertaken especially by diplomacy to achieve these goals through effective impact on the international environment" (Jaworski, 2010, p. 140; Adamczyk \& Baraniuk, 2017, p. 43). Interestingly, in the foreword to Introduction to the Theory of State Foreign Policy edited by Ryszard Zięba, we can find as many as two definitions of foreign policy - according to the first one (quoted after Józef Kukułka), "it is the activity of the highest organized political entity, which is the state; it is one of its public policies and is an outward-facing state activity in the name of state, and the main object of this activity is the development and regulation of relations with other states" (Zięba, 2005c, p. 14). Moreover, the authors of the aforementioned publication adopted the assumption (which in itself constitutes the second definition) that foreign policy is "(...) a process of political activity undertaken by the state, which is addressed and conducted in an international environment. This activity is a part of the general policy of the state, which aims at the realization of specific needs and interests on the international arena" (Zięba, 2005c, p. 14). Finally, it is worth quoting three selected from a whole range of definitions contained in the Lexicon of Political Science (as one of the most important positions of this type on the Polish market of scientific publications). The authors of the lexicon see foreign policy as: "a type of state activity in the international environment. It belongs to the circle of its activity necessary for the existence and development of the external state. It includes intentional actions undertaken to achieve the set objectives and to satisfy specific interests" (Antoszewski \& Herbut, 2004, p. 330; Adamczyk \& Baraniuk, 2017, p. 44). The lexicon also contains two short definitions of foreign policy by Ziemowit Jacek Pietraś and Janusz Symonides, respectively, according to which it is: "(...) a set of actions that the state undertakes to achieve the objectives by exerting influence on other states" (Antoszewski \& Herbut, 2004, p. 331). Undoubtedly, most of the definitions quoted above are largely similar to each other, and their most important common element is the state's activity in the international environment aimed at pursuing its own interests. At the same time, although it is diffi- 
cult to deny them general clarity, it is justified to point out that their authors have not avoided defining ignotum per ignotum - in this case, using an unclear concept of national interest (or reason of state). Ryszard Zięba himself wrote about this problem in one of his articles (2005b, pp. 39-43). Although there are questions and doubts as to whether the side issues related to the attempt to conceptualize the national interest are by no means lacking (see: Burchill, 2005; Kabat-Rudnicka, 2013, pp. 5-42; Kałążna \& Rosicki, 2013, pp. 119-128; Bieleń, 2014, pp. 57-60; Williams, 2005, pp. 307-337; Zięba, 2005b, pp. 39-43; Domański, 2004, pp. 7-25), at the same time not wanting to multiply the threads beyond absolute necessity, we propose to perceive it as a set of internal and external objectives of the state, the implementation of which leads to an increase in its overall strength or at least to the preservation of the status quo/limitation of potential losses.

Coming back to the issue of defining foreign policy, it is worth noting that a different type of objection than in the case of Polish authors can be made to the definition of foreign policy. At the same time, it should be stressed that they are generally more diverse than those functioning in the Polish scientific discourse. Marijke Breuning sees foreign policy as "the totality of a country's policies toward and interactions with the environment beyond its borders" (Breuning, 2007, p. 5). Translating foreign policy as a set of policies, the researcher did not avoid another type of error in defining - idem per idem ${ }^{1}$. However, there are no objections to the definition contained in Foreign Policy Analysis: A Toolbox, where foreign policy was defined as "a set of actions or rules governing the actions of an independent political authority deployed in the international environment" (Morin \& Paquin, 2018, p. 3). It is worth noting that Morin and Paquin further emphasize the importance of "actions of an independent political authority", as only sovereign states conduct foreign policy. The Oxford Handbook of Indian Foreign Policy contains a similar definition (taken, incidentally, directly from a dictionary), according to which foreign policy is: "the policy of a sovereign state in its interaction with other sovereign states" (Madan, 2015, p. 232). Conditioning the ability of a state to exercise foreign policy with sovereignty seems superfluous for the authors, because undoubtedly "the state, while constituting its independence, becomes an independent and sovereign political and legal entity. (...) The state as a political and legal entity gains (...) the possibility to establish and maintain diplomatic relations with other states" (Adamczyk \& Debita, 2018, p. 7). Of course, there is a separate (and at the same time relatively large, because it includes several dozen

${ }^{1}$ At this point we propose to use the definition of politics in formal and legal terms as the activity of state institutions (Antoszewski \& Herbut, 2004, p. 329). 
entities) category of unrecognised states (quasi-, para-, sub-states), which, however, without full formal sovereignty, cannot be a full participant in international relations (see more: Kosienkowski, 2018; Tomczyk, 2017, pp. 121-140; Kosienkowski, 2010; Kosienkowski, 2008, pp. 151-162). On the other hand, Taiwan should also be included in this category de iure, as it is recognised by only a tenth of the international community sensu stricto, but maintains a specific form of diplomatic relations with several dozen countries around the world, while retaining membership in important international organisations - so it is difficult to negate its foreign policy (Kosienkowski, 2008, p. 159; see more: Haliżak, 1997)2 ${ }^{2}$ The same is true of the Palestinian National Authority or the Kurdistan Regional Government (Neack, 2019, p. 8). An interesting point of view is presented by Deborah Gerner, for whom foreign policy is "the intentions, statements, and actions of an actor - often, but not always, a state - directed toward the external world and the response of other actors to these intentions, statements and actions". Charles Hermann's reflections are also noteworthy as he perceives foreign policy in terms of behavior of states and defines it in a very original way as "the discrete purposeful action that results from the political level decision of an individual or group of individuals" (Neack, 2019, p. 7).

Slowly moving towards the end of our definitions, it is worth quoting the former Japanese Ambassador to Costa Rica, who sees foreign policy as similar to Polish scientists: "a policy formulated by a nation in its dealing with other nations, in order to preserve national interests and/or achieve national objectives" (Shinohara, 2017, p. 3). As can be seen, the author unfortunately did not avoid the aforementioned mistakes in defining, but on the other hand, it is worth noting the importance of maintaining the status quo as one of the objectives of foreign policy. On the basis of this and previous definitions (while taking into account potential reservations regarding the interchangeable use of terms between the state and the nation $)^{3}$, we propose our own approach to foreign policy as an activity of the state in relations with other states leading to the implementation of previously formulated national goals. In this way, we avoided defining foreign policy as one of the policies or linking it with an ambiguous notion of national interest. At the end of the definition, it is worth stressing clearly that in a modern, interdependent world,

${ }^{2}$ In this context, the refusal of domestic researchers to always emphasize sovereignty in the context of a country's ability to conduct foreign policy seems justified in all respects.

3 As General Stanisław Koziej pointed out, in the era of modern nation states, when talking about their security policy, this practice is as frequent as it is justified (Koziej, 2011, p. 20). In our opinion, this view can certainly be extrapolated to foreign policy. 
the foreign policy of democratic states ${ }^{4}$ must be perceived not only as a result of internal policy, but also to an increasing extent as an effect of the influence of the international environment (Neack, 2019, pp. 4, 9; Alden \& Aran, 2017, p. 1). It should be remembered that although the following statement may seem trivial, foreign policy is not independent of the domestic policy of the state, but neither of them should take precedence over the other (Kuźniar, 2005, p. 123) - by interacting with each other (and being subject to the aforementioned external influences) they lead to the achievement of the assumed state/national goals. This reflection is so important that it allows us to understand why, within the framework of foreign policy research, we can take into account factors from the individual or state level, as well as from the level of the international system (Neack, 2019, pp. 9-11; see more: Waltz, 2001).

\section{Foreign Policy Determinants}

Close relations between internal and external state policy can be seen in the analysis of conditions (determinants) of foreign policy. In the national literature of the subject, determinants are divided according to two criteria: objective and subjective determinants and factors of internal and external provenance (Adamczyk \& Baraniuk, 2017, p. 44; Jaworski, 2010, p. 140; Sajduk, 2009, pp. 66-67; Kuźniar, 2006, p. 123; Zięba, 2005a, p. 20). Thus, it is possible to specify four types of conditions: internal objective, internal subjective, and external objective and external subjective. These factors are mostly responsible for its structure and the instruments available to it. The first category (internal objective factors) includes: geographical environment (size and shape of the territory, course of borders, climate or natural resources), demographic potential (population size, national and age structure, enrolment rate, population density, most important directions of migration), economic and scientific and technical potential (size of the economy and pace of its development, technological advancement and inclination to innovativeness, structure and balance of foreign trade, dependence on imports of strategic raw materials, size of foreign investments, economic system, membership in international economic organisations, etc.), military potential (amount and structure of defence expenditures, size of particular types of armed forces, their

${ }^{4}$ As Michał Bogusz (2017) rightly points out, in authoritarian states, foreign policy often plays a servant role in relation to domestic policy - which is perfectly visible in the case of Russia and China. 
technological advancement, level of training and morale, distribution of military bases in the country and in the world, involvement in armed conflicts, size and advancement of military industry but also military traditions), social and political system (form of governance, functioning of administration, activity of political parties, role of media and public opinion) (Jaworski, 2010, pp. 144-145; Sajduk, 2009, pp. 68-69; Kuźniar, 2006, pp. 123-124; Zięba, 2005a, pp. 21-26). Another category of factors of internal origin are the determinants of subjective character in the form of perception of the international environment (which is influenced by historical experience, dominant religion and ideology, strategic culture or penitent stereotypes about other nations or the so-called "national nature"); it is also a matter of the quality and activity of foreign service and diplomacy professionalism of politicians and officials dealing with foreign policy, number and location of diplomatic and consular posts, initiative in the international arena (Jaworski, 2010, pp. 145-146; Sajduk, 2009, pp. 77-78; Kuźniar, 2006, pp. 124-125; Zięba, 2005a, pp. 26-29).

Among the determinants of external provenance and objective character one can distinguish: prevailing trends in the evolution of the international environment (their influence on the foreign policy of the state, but also the influence of the state on their creation; nowadays, examples of such trends may be the decreasing significance of the Westphalian order, the reverse of liberal democracy, the development of religious extremism, etc.), the position and role of the state within international relations (resulting directly from its potential, but also from its image or being socially constructed), as well as international agreements concluded and membership in international organizations (they necessarily affect the need to "self-limit" the state on the one hand, and to increase the importance of some foreign policy instruments at the expense of others on the other) (Jaworski, 2010, p. 147; Sajduk, 2009, pp. 74-75; Zięba, 2005a, p. 30). On the other hand, external subjective determinants include: international perception of the state and nation and expectations towards them (countries with an established image of trustworthy partners will usually be able to conduct a more effective foreign policy than pariahs, although at the same time the image of an aggressive and unpredictable state may lead to other concessions towards it), foreign policy concepts of other members of the international community sensu stricto or the quality of their foreign service (the more aggressive concepts of foreign policy and professional diplomacy of other states at the same time, the more challenges the foreign policy of a given state faces) (Jaworski, 2010, p. 148; Sajduk, 2009, pp. 78; Zięba, 2005a, pp. 33-35). 


\section{Structure and Instruments of Foreign Policy}

A proper analysis of the foreign policy structure of a country should also include its principles, objectives and main directions/areas of interest (in a geographical sense). Principles can be seen as superior values that the state follows (at least in the declarative sphere) in its relations with other states (e.g., promotion of democracy and human rights, non-interference in internal affairs, etc.) (Kuźniar, 2006, pp. 125-126).

The analysis of the principles constituting foreign policy is important because countries tend to use it instrumentally, opposing their own principles with those of their competitors on the international arena, and at the same time presenting them as a new quality in international politics. Foreign policy objectives can be understood as the result of a country's external activity, which is desired by the country. In the literature on the subject, there are many typologies of these goals, so in the following section we will only present selected examples, which in our opinion are the most useful for studying the foreign policy of contemporary countries. Roman Kuźniar suggests that foreign policy goals should be divided according to three criteria:

- time (short, medium and long term goals),

- content (existential goals, i.e., survival and security in both negative and positive terms (see: Olak \& Olak, 2016, p. 475), coexistence (enabling the state to function in the international environment in accordance with its expectations) and functionality (aimed at increasing effectiveness in the implementation of the two previous ones),

- as well as meaning (basic, i.e., vital goals; main goals, i.e., important, but at a given moment; and secondary goals) (Kuźniar, 2006, p. 125; Adamczyk \& Baraniuk, 2017, p. 45).

Arnold Wolfers proposed a typology interesting from the point of view of the analysis of foreign policy of future hegemonic states. He distinguished three categories of goals: goals of self-extention (to seek to change the existing order), goals of self-preservation (maintenance of possessions), and goals of self-abnegation (commitment to the welfare of the international community) (Zięba, 2005b, p. 44; Adamczyk \& Baraniuk, 2019, p. 188). Steven Westley Mosher, on the other hand, proposed that the foreign policy objectives of contemporary China should be viewed from the perspective of an interesting spatial criterion within which we can distinguish three levels of analysis (Adamczyk \& Bararniuk, 2019, pp. 188$-189)$ - there seems to be no reason why this criteria should not be used primarily 
for examining the foreign policy of the superpowers, as these, by definition, have global objectives 5 .

Foreign policy means (instruments) ${ }^{6}$ in the simplest sense of the term are all that a country has and actively uses to achieve its goals (in foreign policy). There are also a number of typologies in their case, but the most important (and at the same time probably the most intuitive) is the subject criteria, which allows to divide the instruments according to areas into: political, economic, military, psychosocial, and normative (Kuźniar, 2006, p. 127; Adamczyk \& Baraniuk, 2017, pp. 45-46). Political instruments cover everything connected with maintaining diplomatic relations and contacts between politicians at various levels. On the other hand, economic measures are an extremely broad category, so they are usually divided into positive (i.e., those that support other countries, such as development aid, investments, trade preferences, etc.) and negative (all that allows pressure to be exerted, such as embargoes, discrimination, etc.) (Kuźniar, 2006, p. 125; Adamczyk \& Baraniuk, 2017, pp. 45-46). Also military instruments can be divided into negative (demonstrations and threats of the use of force, international military interventions, independent military actions) and positive (provision of intelligence, sale and free supply of weapons, support for training and planning, transfer of military technology, etc.). It should be noted that in the face of the prohibition on the use of force in international relations, many scientists have downgraded the importance of such instruments, which, given the growing military expenditure of the world's leading countries (see: Tian et al., 2019, pp. 2-3, 8) or the aggressive policy of the Russian Federation and China towards neighbouring countries, seems to be an overgrown criticism. Another category are psychosocial measures, which aim at shaping favourable social moods in other countries through attractiveness and activity in the cultural, scientific, informational, etc., fields (see more: Nye, 2007). The last category in the typology cited above are normative instruments that concern the involvement of the state in shaping the international legal order (Kuźniar, 2006, pp. 127-128; Adamczyk \& Baraniuk, 2017, p. 46). It is also worth noting the specific foreign policy instrument of special services (mainly foreign intelligence services), which escape rigid classification according to the subject criterion (Jaworski, 2010, p. 153). Their main objective is to obtain and process information which, by reaching decision-makers (in the form of reports), may influence decisions and the use of the most appropriate means in foreign pol-

5 Which could be controversial for countries with much lower ambitions.

${ }^{6}$ Some authors point out that measures are a broader concept, as apart from instruments, they also include undefined resources (Jaworski, 2010, p. 151); for the purposes of this study, these terms will be used interchangeably. 
icy. Moreover, while conducting operations abroad, intelligence can also function as an economic instrument (e.g., lobbying for concerns or specific agreements), psychosocial (using tools of international influence available to a given country - including psychological warfare), military (e.g., exchanging information with the services of friendly countries, training their officers, taking part in arms sales transactions or finally supporting their own armed forces or disintegrating the forces of their opponents). The above mentioned features of the activity of special services make it necessary to treat them as a separate category of foreign policy instruments (Adamczyk \& Baraniuk, 2019, pp. 189-190). Jean-Frédéric Morin and Jonathan Paquin propose a different categorisation of foreign policy instruments. In contrast to the aforementioned scholars, Morin and Paquin formulated only three categories of instruments that are in the hands of the state: socialization ("transfer of beliefs, values and ideas from one actor to another", Morin \& Paquin, 2018, p. 32), coercion ("measures [which] are designed to influence how a target state behaves by modifying the way its interests are calculated, without directly intervening in foreign territory", Morin \& Paquin, 2018, p. 35), and intervention ("incursions in the domestic affairs of a foreign state to bring about internal structural change" - both political and also military, Morin \& Paquin, 2018, p. 35).

\section{Instead of a Summary}

On the previous pages we presented a number of definitions of foreign policy (as well as proposed our own $)^{7}$, and described in detail its determinants (internal and external as well as subjective and objective), structure (i.e., principles, objectives and main directions of interest), as well as instruments available to the state within the framework of foreign policy to pursue its own national interest (whose definition we also formulated $)^{8}$. As announced in the introduction to this article, it is therefore time to present potential practical research solutions for the approach we have presented. It is obvious that using the comparative method one can juxtapose the conditions, structure and instruments of foreign policy of any country in the world. However, a potentially interesting procedure is to compare countries with similar conditions (such as Scandinavian, Baltic or Central Asian countries) in

\footnotetext{
${ }^{7}$ In our opinion, foreign policy is the state's activity in relations with other states leading to the achievement of previously formulated national goals.

${ }^{8}$ National interest is understood as all the internal and external objectives of a state, the achievement of which leads to an increase in its overall strength or at least to the maintenance of the status quo/reduction of potential losses.
} 
order to study to what extent the structure and/or instruments of foreign policy of these countries are similar to each other. One can also focus on the comparison of countries whose foreign policy is determined by completely different factors of internal provenance, but with similar external conditions (position in the international system or role in the international community) - this comparison may refer to global (the USA and China) or regional (Russia, Germany, India, Brazil, South Africa) powers, or medium/lower peripheral countries. In this way, we can try to answer the question: which of the factors determining foreign policy have a greater impact on it - internal or external determinants? Another research scenario is the analysis of countries with a similar foreign policy structure (with particular emphasis on rules) in order to show the impact of the determinants on its formation. Finally, we can also present how far-reaching is the relationship between them and the range of foreign policy instruments that modern states use - an interesting starting point for such an analysis would be a research question about which of the determinants are more important - subjective or objective? In fact, there are many potential research scenarios, but what is important is to be aware of what elements of foreign policy and why we compare them. Of course, a similar exception also applies to countries selected for research.

\section{References:}

Adamczyk, M., \& Baraniuk, K. (2017). Wywiad jako instrument chińskiej polityki zagranicznej - przyczynek do badań. Studia Orientalne, 11(1), 41-71.

Adamczyk, M., \& Baraniuk, K. (2019). People's Republic of China as a Global Actor of International Relations - Role of Intelligence in Chinese Foreign Policy. Kultura - Historia - Globalizacja, 25, 187-197.

Adamczyk, M., \& Debita, M. (2018). Zasada nieingerencji w sprawy wewnętrzne innego kraju oraz jej miejsce w polityce zagranicznej Chińskiej Republiki Ludowej. Studia Orientalne, 14(2), 7-32. DOI: 10.15804/so2018201.

Alden, C., \& Aran, A. (2017). Foreign Policy Analysis: New Approaches. Milton Park: Routledge.

Antoszewski, A., \& Herbut, R. (eds.). (2004). Leksykon politologii. Wrocław: Atla 2.

Bieleń, S. (2014). Rozważania o polskim interesie narodowym. Stosunki Międzynarodowe - International Relations, 50(2), 57-73.

Bogusz, M. (2017, December 19). Cel KPCh. Za Wielkim Murem: Chiny i Azja. Retrieved from: https://zawielkimmurem.net/2017/12/19/polecany-wpis-cel-kpch/.

Breuning, M. (2007). Foreign Policy Analysis: A Comparative Introduction. New York: Palgrave Macmillan.

Burchill, S. (ed.). (2005). The National Interest in International Relations Theory. London: Palgrave Macmillan. DOI: 10.1057/9780230005778. 
Domański, H. (2004). Racja stanu a interesy narodu. Nauka, 3, 7-25.

Haliżak, E. (ed.). (1997). Tajwan w stosunkach międzynarodowych. Warszawa: Wydawnictwo Naukowe Scholar.

Jaworski, K. (2010). Teoretyczne aspekty analizy polityki zagranicznej państwa. Myśl Ekonomiczna i Polityczna, 3, 139-181.

Kabat-Rudnicka, D. (2013). Pojęcie interesu w perspektywie głównych ujęć teoretycznych stosunków międzynarodowych. Polski Przegląd Stosunków Międzynarodowych, 3, 5-42. DOI: 10.21697/PPSM.2013.01.

Kałążna, K., \& Rosicki, R. (2013). O interesie narodowym i racji stanu - rozważania teoretyczne. Przegląd Politologiczny, 1, 119-128. DOI: 10.14746/pp.2013.18.1.9.

Kosienkowski, M. (2008). Quasi-państwo w stosunkach międzynarodowych. Stosunki międzynarodowe - International Relations, 38(3-4), 151-162.

Kosienkowski, M. (2010). Naddniestrzańska Republika Motdawska: determinanty przetrwania. Toruń: Wydawnictwo Adam Marszałek.

Kosienkowski, M. (2018). Wspótpraca spoteczności międzynarodowej z państwami de facto. Studium przypadków. Lublin: Wydawnictwo KUL.

Koziej, S. (2011). Bezpieczeństwo: istota, podstawowe kategorie i historyczna ewolucja. Bezpieczeństwo Narodowe, 2, 19-39.

Kuźniar, R. (2006). Międzynarodowe stosunki polityczne. In: E. Haliżak, \& R. Kuźniar (eds.). Stosunki międzynarodowe. Geneza, struktura, dynamika (pp. 119-141). Warszawa: Wydawnictwo Uniwersytetu Warszawskiego.

Madan, T. (2015). Officialdom: South Block and Beyond. In: D.M. Malone, C.R. Mohan, \& S. Raghavan (eds.). The Oxford Handbook of Indian Foreign Policy (pp. 232-246). Oxford: Oxford University Press. DOI: 10.1093/oxfordhb/9780198743538.013.17.

Morin, J.F., \& Paquin, J. (2018). Foreign Policy Analysis. A Toolbox. Cham: Palgrave Macmillan.

Neack, L. (2019). Studying Foreign Policy Comparatively: Cases and Analysis. Lanham: Rowman \& Littlefield.

Nye, J.S. (2007). Soft power. Jak osiagnací sukces w polityce światowej. Warszawa: Wydawnictwa Akademickie i Profesjonalne.

Olak, K., \& Olak, A. (2016). Współczesne rozumienie bezpieczeństwa narodowego. Acta Scientifica Academiae Ostroviensis. Sectio A, Nauki Humanistyczne, Spoteczne i Techniczne, 7(1), 467-480.

Sajduk, B. (2009). Tradycyjne metody analizy polityki zagranicznej. In: K. Szczerski (ed.). Podmiotowość geopolityczna. Studia nad polska polityka zagraniczna (pp. 59-86). Warszawa: Krajowa Szkoła Administracji Publicznej.

Shinohara, M. (2017). The Foreign Policy of Japan. Ideas for Peace, 11, 1-12.

Skrzyp, J. (2018). Chiny i Stany Zjednoczone Ameryki w ujęciu geopolitycznym. Przegląd Geopolityczny, 23(2), 9-23.

Tian, N., Fleurant, A., Kuimova, A., Wezeman, P.D., \& Wezeman, S.T. (2019). SIPRI Fact Sheet April 2019: Trends in World Military Expenditure, 2018. Stockholm: Stockholm International Peace Research Institute. 
Tomczyk, A. (2017). Czy quasi-państwo to też państwo? Refleksja nad analizą pojęciową wybranych aspektów istnienia państwa i quasi-państwa. Politeja, 3(48), 121-140. DOI: 10.12797/Politeja.14.2017.48.07.

Waltz, K. (2001). Man, the State, and War: A Theoretical Analysis. New York: Columbia University Press.

Williams, M.C. (2005). What is the National Interest? The Neoconservative Challenge in IR Theory. European Journal of International Relations, 11(3), 307-337. DOI: $10.1177 / 1354066105055482$.

Zięba, R. (2005a). Uwarunkowania polityki zagranicznej państwa. In: R. Zięba (ed.). Wstęp do teorii polityki zagranicznej państwa (pp. 17-35). Toruń: Wydawnictwo Adam Marszałek.

Zięba, R. (2005b). Cele polityki zagranicznej państwa. In: R. Zięba (ed.). Wstęp do teorii polityki zagranicznej państwa (pp. 37-58). Toruń: Wydawnictwo Adam Marszałek.

Zięba, R. (2005c). Przedmowa. In: R. Zięba (ed.). Wstęp do teorii polityki zagranicznej państwa (pp. 13-15). Toruń: Wydawnictwo Adam Marszałek. 